\title{
Pengembangan Media Pembelajaran Interaktif Berbantu Software iSpring terhadap Retensi Mahasiswa pada Konsep Kalkulus II
}

\author{
Shinta Dwi Handayani ${ }^{1}$, Aulia Ar Rakhman Awaludins ${ }^{2}$ \\ ${ }^{1,2}$ Universitas Indraprasta PGRI \\ ${ }^{1}$ shintadh.1109@gmail.com, ${ }^{2}$ aulia_awaludin@yahoo.co.id
}

\begin{tabular}{|c|c|}
\hline Article Info & Abstract \\
\hline Article history: & \multirow{6}{*}{$\begin{array}{l}\text { The purpose of this study is to develop iSpring software } \\
\text { aided interactive learning against student retention on } \\
\text { the concept of calculus II. This type of research is RnD } \\
\text { research. The development procedure, will be dividea } \\
\text { into } 4 \text { parts, namely preliminary analysis, } \\
\text { implementation and preparation of learning media, } \\
\text { validation and revision, and small-scale trials (limited) } \\
\text { The sampling technique that I use is to use simple } \\
\text { random sampling. The results show that there is a } \\
\text { positive influence, student retention on student learning } \\
\text { achievement in learning calculus II. }\end{array}$} \\
\hline Received April $18^{\text {th }}, 2020$ & \\
\hline Revised May $15^{\text {th }}, 2020$ & \\
\hline Accepted May $30^{\text {th }}, 2020$ & \\
\hline Keywords: & \\
\hline $\begin{array}{l}\text { Developme } \\
\text { iSpring Me } \\
\text { Retention }\end{array}$ & \\
\hline
\end{tabular}

Kata Kunci:

Tujuan penelitian ini adalah mengembangkan

Pengembangan; pembelajaran interaktif berbantu software iSpring

Media iSpring; terhadap retensi mahasiswa pada konsep kalkulus II.

Retensi Jenis penelitian ini merupakan penelitian RnD. Prosedur pengembangan, akan dibagi menjadi 4 bagian, yaitu analisis pendahuluan, pelaksanaan dan penyusunan media pembelajaran, validasi dan revisi, dan uji coba skala kecil (terbatas). Teknik sampling yang saya gunakan adalah dengan menggunakan simple random sampling. Diperoleh hasil bahwa terdapat pengaruh positif, retensi mahasiswa terhadap prestasi belajar mahasiswa dalam pembelajaran kalkulus II.

\section{PENDAHULUAN}

Pendidikan adalah salah satu kebutuhan dasar manusia, karena pada dasarnya pendidikan merupakan suatu proses untuk membantu manusia 
90 | Handayani dan Awaludins: Pengembangan Media Pembelajaran Interaktif ...

dalam mengembangkan dirinya sehingga mampu untuk menghadapi setiap perubahan yang terjadi (Pinahayu,2015:182). Matematika merupakan ilmu universal yang mendasari perkembangan teknologi modern, mempunyai peran penting dalam berbagai disiplin dan memajukan daya pikir manusia (Priambodo, et al., 2017: 59). Kalkulus (bahasa Latin: calculus, artinya 'batu kecil', untuk menghitung) adalah cabang ilmu matematika yang mencakup limit, turunan, integral, dan deret tak hingga. Kalkulus merupakan ilmu dasar yang perlu dikuasai secara lebih luas dan mendalam oleh para mahasiswa, calon guru, atau calon ilmuwan. Mahasiswa yang menguasai mata kuliah kalkulus akan sangat membantu dalam mengikuti mata kuliah selanjutnya, karena memang kalkulus wajib dikuasai oleh mahasiswa. Mahasiswa yang belum menguasai konsep kalkulus tentunya akan menghambat proses pembelajaran, karena dosen harus mengulang kembali materi yang seharusnya sudah dikuasai mahasiswa pada semester sebelumnya.

Rendahnya kemampuan kalkulus mahasiswa dilihat dari hasil tes belajar mahasiswa yang masih rendah. Rata-rata nilai akhir mahasiswa pada mata kuliah kalkulus lanjut tahun akademik 2015/2016 yang berkisar pada 57,73, artinya rata-rata tersebut jika dikonversi ke nilai huruf memberikan nilai C. Tentunya rendahnya kemampuan kalkulus mahasiswa tidak terlepas dari peran dosen. Salah satu alasan yang cukup rasional mungkin selama ini kegiatan pembelajaran kalkulus dapat dikatakan kurang menarik dan kurang interaktif. Dosen juga jarang menggunakan media pembelajaran, padahal kalkulus termasuk mata kuliah yang sulit dan memerlukan penalaran yang cukup baik. Misalnya dalam mengambarkan grafik suatu fungsi, mahasiswa sering sekali keliru, apalagi menggambarkan grafik dalam bidang tiga dimensi. Pada semester satu dan tiga, mahasiswa sudah memperoleh mata kuliah komputer dasar dan aplikasi komputer, tetapi Dosen tidak pernah mengaitkan materi komputer, yaitu iSpring dengan mata kuliah yang diajarkan, salah satunya kalkulus, padahal materi tersebut dapat membantu mahasiswa dalam belajar untuk lebih kontruktivis. 
Pengembangan media pembelajaran konstruktivis dengan menggunakan TIK seperti komputer tentunya memanfaatkan suatu software atau perangkat lunak untuk membuat animasi yang menarik dalam waktu yang cepat seperti Microsoft PowerPoint yang sering kita jumpai dalam program komputer. Microsoft PowerPoint merupakan program untuk membuat presentasi dengan fasilitas yang ada dapat digunakan untuk membuat media pembelajaran, program yang dihasilkan cukup menarik jika digabungkan dengan menggunakan software iSpring Presenter yang dapat merubahnya menjadi media animasi dalam bentuk flash.

Keunggulan lainnya dari tampilan media berbantu software iSpring Presenter adalah kemampuannya dalam menghadirkan ilustrasi atau visualisasi dari obyek-obyek yang sebenarnya tidak ada secara fisik atau diistilahkan dengan imagery. Menurut Matlin (1994) menyatakan bahwa secara kognitif, pembelajaran dengan menggunakan mental imagery akan meningkatkan retensi mahasiswa dalam mengingat materi-materi yang sedang dipelajari. Ilustrasi yang dihadirkan bertujuan memperjelas pesan atau informasi yang disampaikan. Ilustrasi juga dimaksudkan untuk memberi variasi pada media pembelajaran sehingga menjadi lebih menarik dan membangun, komunikatif, dan lebih memudahkan mahasiswa dalam memahami pesan. Menurut Pannen dan Purwanto (2005) menghadirkan ilustrasi dalam pembelajaran dapat juga membantu retensi, yaitu memudahkan mahasiswa untuk mengingat konsep atau gagasan yang disampaikan melalui ilustrasi.

Dalam berbagai referensi diperoleh informasi bahwa pembelajaran interaktif berbantuan komputer merupakan alat pembelajaran yang efektif dalam membangun pemahaman suatu konsep dan memiliki kekuatan dalam memberikan proses pembelajaran yang aktif dan kreatif serta mendukung proses belajar yang berorientasi pada siswa. Kusumah (dalam Hendrayana, 2008) menyatakan bahwa informasi yang disajikan dalam bentuk animasi, dapat memberikan kesan mendalam dan memberikan retensi (daya ingat) yang lama pada diri mahasiswa. 
Atas dasar permasalahan penulis memiliki tujuan mengembangkan pembelajaran interaktif berbantu software iSpring terhadap retensi mahasiswa pada konsep kalkulus II, terdapat pengaruh yang positif, retensi mahasiswa terhadap prestasi belajar mahasiswa dalam pembelajaran kalkulus II.

\section{METODE PENELITIAN}

Jenis Penelitian ini merupakan penelitian Riset and Development (RnD). Teori yang digunakan adalah Teori pengembangan Borg dan Gall. Prosedur pengembangan, akan dibagi menjadi 4 (empat) bagian, yaitu analisis pendahuluan, pelaksanaan dan penyusunan media pembelajaran, validasi dan revisi, dan uji coba skala kecil (terbatas). Teknik sampling yang digunakan adalah dengan menggunakan simple random sampling. Populasi dalam penelitian ini adalah seluruh mahasiswa semester II Universitas Indraprasta PGRI. Sampel dalam penelitian ini adalah mahasiswa/i kelas R2Q dan R2O Universitas Indraprasta PGRI. Analisis data awal dibagi menjadi dua, yaitu untuk menentukan kelas sampel dan menentukan kelayakan tes kemampuan pemahaman konsep dengan uji normalitas menggunakan uji Lilliefors, uji homogenitas, dan uji kesamaan dua rata-rata digunakan uji-t. Sedangkan analisis data akhir ini terdapat empat kegiatan, yaitu uji keterbacaan, efektivitas penggunaan produk, dan perbedaan.

\section{HASIL PENELITIAN DAN PEMBAHASAN}

\section{Hasil Penelitian}

Hasil Validasi Perangkat

Berdasarkan hasil validasi ahli (pakar) dengan Bapak Caka Gatot Priambodo, M.Kom. selaku pakar media dan Ibu Anggun Citra Dini Suhendar, M.Pd. pakar bahasa dari Universitas Indraprasta PGRI, Jakarta pada media pembelajaran yang digunakan dengan kriteria baik. Rata-rata nilai dari masing-masing validator dapat dilihat dari Tabel 1. 
Tabel 1. Rata-rata Nilai Validator

\begin{tabular}{cc}
\hline Validator & CD Interaktif \\
\hline A & 47 \\
B & 47 \\
C & 48 \\
Rata-rata & 47,3 \\
Kriteria & Baik \\
\hline
\end{tabular}

Hasil Validasi ahli menunjukkan bahwa dengan melakukan sedikit revisi, maka media pembelajaran interaktif berbantu iSpring terhadap retensi mahasiswa akan valid.

a. Hasil Uji Coba Perangkat Tes

Dalam penelitian ini digunakan tes prestasi 5 soal uraian yang harus dikerjakan siswa dalam waktu 75 menit.

b. Hasil Uji Coba Terbatas

Hasil uji coba terbatas dilakukan untuk mengetahui apakah pembelajaran dengan menggunakan media pembelajaran interaktif berbantu iSpring terhadap retensi mahasiswa efektif dan baik.

1) Uji Normalitas dan Homogenitas Awal (Uji Prasyarat)

Tabel 2. Uji Normalitas Kelas Eksperimen

\begin{tabular}{|c|c|c|c|r|c|c|}
\hline \multirow{2}{*}{} & \multicolumn{3}{|c|}{ Kolmogorov-Smirnov } & \multicolumn{3}{c|}{ Shapiro-Wilk } \\
\cline { 2 - 7 } & Statistic & df & Sig. & Statistic & df & Sig. \\
\hline Nilai & .125 & 22 & .200 & .957 & 22 & .426 \\
\hline
\end{tabular}

Nilai kemampuan awal mahasiswa diambil dari nilai Ujian Tengah Semester II kelas R2O tahun ajaran 2016/2017. Uji normalitas data awal pada kelas eksperimen diperoleh $\mathrm{L}_{\text {tabel }}=0,1832$ dan $\mathrm{L}_{0}=0,126$. Sementara itu pada perhitungan SPSS, diperoleh sig.n $=0,426$ dengan taraf signifikansi $95 \%$ sehingga diperoleh hubungan sig.n $>0,05$ yaitu $0,426>0,05$.

Tabel 3. Uji Normalitas Kelas Kontrol

\begin{tabular}{|c|c|c|c|r|r|c|}
\hline \multirow{2}{*}{} & \multicolumn{3}{|c|}{ Kolmogorov-Smirnov } & \multicolumn{3}{c|}{ Shapiro-Wilk } \\
\cline { 2 - 7 } & Statistic & df & Sig. & Statistic & df & Sig. \\
\hline Nilai & .163 & 23 & .118 & .945 & 23 & .235 \\
\hline
\end{tabular}


Sedangkan uji normalitas pada kelas kontrol diperoleh $\mathrm{L}_{\text {tabel }}=0,180$ dan $\mathrm{L}_{0}=0,163$. Sementara itu pada perhitungan SPSS, diperoleh sig.n $=0,235$ dengan taraf signifikansi 95\% sehingga diperoleh hubungan sig.n $>0,05$ yaitu $0,235>0,05$. Dari perhitungan diperoleh bahwa data kedua kelas tersebut berdistribusi normal berarti mempunyai sebaran data yang normal pula.

Untuk pengujian homogenitas kelas eksperimen dan kelas kontrol dipakai uji $\mathrm{F}$ dan diperoleh $\mathrm{F}_{\text {hitung }}=1,059$ dan $\mathrm{F}_{\text {Tabel }}=2,020$. Sedangkan pada perhitungan SPSS diperoleh sig. $\mathrm{n}=0,508$ dengan taraf signifikansi 95\% sehingga diperoleh hubungan sig.n $>0,05$ yaitu 0,508>0,05. Dari perhitungan manual dan SPSS diperoleh kesimpulan bahwa data tersebut homogen yang artinya himpunan data kelas kontrol dan kelas eksperimen mempunyai varians dan karakteristik yang sama.

2) Uji Ketuntasan Klasikal Kelas Eksperimen

Pengujian ini dilakukan untuk memenuhi salah satu indikator keefektifan pembelajaran pada kelas eksperimen yakni tercapainya ketuntasan prestasi belajar kalkulus II dengan Kriteria Ketuntasan Minimal (KKM) sebesar 75. Dengan rata-rata kelas eksperimen sebesar 83,068 diperoleh $t_{\text {hitung }}=3,7$ sedangkan $t_{\text {tabel }}=1,72$. Dengan demikian $t_{\text {hitung }}>t_{\text {tabel }}$, maka $\mathrm{H}_{0}$ ditolak artinya prestasi belajar kalkulus II kelas eksperimen sudah mencapai rata-rata ketuntasan belajar yang diprogramkan 75 .

3) Uji Ketuntasan Individual Kelas Eksperimen

Untuk menguji ketuntasan individual digunakan uji proporsi dua pihak. Dengan menggunakan rumus $z$ dan $x$ kelas eksperimen sebanyak 22 siswa diperoleh $z_{\text {hitung }}=0,746$ sedangkan $z_{\text {tabel }}=1,645$. Dengan demikian $\mathrm{z}_{\text {hitung }}<\mathrm{z}_{\text {tabel }}$, maka $\mathrm{H}_{0}$ diterima artinya proporsi mahasiswa kelas eksperimen yang mencapai KKM 75 adalah $80 \%$.

4) Uji Regresi

Variabel independent $(X)$ adalah retensi mahasiswa dengan berbantu media pembelajaran interaktif iSpring $(Y)$ adalah prestasi belajar peserta didik. Dari hasil perhitungan manual dan SPSS diperoleh nilai $a=12,132$ dan $b=1,773$, jadi persamaan regresinya 
adalah $\hat{Y}=12,132+1,773 \mathrm{X}$. Persamaan regresi tersebut berarti aktivitas peserta didik dalam proses pelaksanaan pembelajaran berpengaruh positif terhadap prestasi kalkulus II mahasiswa kelas R2O dalam melaksanakan proses belajar karena mempunyai nilai $b=1,773$. Nilai $a=12,132$ merupakan pengaruh lain yang diberikan selain dari aktivitas peserta didik, karena nilai $a$ adalah positif maka pengaruh faktor lain memberi kontibusi yang positif pula terhadap prestasi belajar peserta didik.

5) Uji $t$ satu pihak (pihak kanan) rataan prestasi belajar kelas eksperimen dengan kelas kontrol.

Diperoleh bahwa $\mathrm{F}_{\text {tabel }}=2,02$ dan $\mathrm{F}_{\text {hitung }}=1,099$ maka data tersebut homogen karena $\mathrm{F}_{\text {Hitung }}<\mathrm{F}_{\text {Tabel }}$ yang artinya himpunan data kelas kontrol dan kelas eksperimen mempunyai varians dan karakteristik yang sama. Sehingga uji perbedaan rataannya menggunakan uji $t$ homogen. Diperoleh $t_{\text {tabel }}=1,680$ dan $t_{\text {hitung }}=6,536$, karena $t_{\text {hitung }}>$ $t_{\text {tabel }}$ maka $\mathrm{H}_{0}$ ditolak artinya rata-rata prestasi belajar kelas eksperimen lebih baik daripada kelas kontrol.

\section{Pembahasan}

Menurut Suryadi (2007: 83-98) memaparkan hasil penelitian selama 10 tahun oleh proyek Apple Classroom of Tomorrow (ACOT) dan menyimpulkan bahwa inovasi-inovasi paedagogis dan hasil-hasil positif pembelajaran dapat diperoleh dengan penerapan teknologi (ICT) di sekolah. Dipertegas dengan pendapat Muijis dan Reynolds (2008: 347352), bahwa penggunaan ICT dapat memberikan konstribusi positif pada pembelajaran murid, ini bisa terjadi jika ICT yang digunakan dalam proses pembelajaran bersifat interaktif. iSpring Presenter adalah kemampuannya dalam menghadirkan ilustrasi atau visualisasi dari obyekobyek yang sebenarnya tidak ada secara fisik atau diistilahkan dengan imagery. Menurut Matlin (1994) menyatakan bahwa secara kognitif, pembelajaran dengan menggunakan mental imagery akan meningkatkan retensi mahasiwa dalam mengingat materi-materi yang sedang dipelajari. Ilustrasi yang dihadirkan bertujuan memperjelas pesan atau informasi yang disampaikan. 
Deese, et al. (1975), menyatakan bahwa retensi merupakan salah satu aspek utama pembelajaran manusia dan tingkah laku kerja yang dipelajari melalui metode percobaan. Sementara itu, Elis (dalam Saguni, 2006) mengemukakan bahwa memori mengacu pada penyimpanan informasi dan mengakses informasi yang pernah diterima. Lebih lanjut dkatakan bahwa pada dasarnya memori mencakup proses encoding (penyandian), storage (penyimpanan), dan retrieval (memanggil kembali). Jadi, memori berkaitan dengan penerimaan informasi, penyimpanan informasi, sampai kepada pemanggilan informasi yang disimpan.

Dengan demikian media pembelajaran interaktif berbantu iSpring terhadap retensi mahasiswa, sudah memenuhi tiga hal yaitu media pembelajaran valid berdasarkan penilaian validator. Uji coba lapangan yang menghasilkan pembelajaran yang efektif, yaitu prestasi belajar peserta didik kelas eksperimen pada pembelajaran kalkulus kelas R2O telah mencapai ketuntasan klasikal maupun individual yang diinginkan. Terdapat pengaruh positif, retensi mahasiswa terhadap prestasi belajar mahasiswa dalam pembelajaran kalkulus II.

\section{SIMPULAN}

Berdasarkan proses pengembangan media pembelajaran interaktif berbantu iSpring terhadap retensi mahasiswa konsep kalkulus II dengan teori pengembangan Borg dan Gall, dapat disimpulkan proses dan hasil pengembangan media pembelajaran interaktif berbantu iSpring terhadap retensi mahasiswa konsep kalkulus II valid sedangkan pembelajaran kalkulus II dengan media pembelajaran interaktif berbantu iSpring lebih efektif daripada pembelajaran konvensional.

\section{DAFTAR PUSTAKA}

Deese, et al. (1975). The Psychology of Learning. London: Mc. Graw Hill Book Co

Hendrayana, A. (2008). Pengembangan Multimedia Interaktif untuk Meningkatkan Kemampuan Berpikir Kritis dan Kreatif Siswa SMP 
dalam Matematika. Tesis Magister Program Pascasarjana UPI: tidak diterbitkan

Matlin, M. W. (1994). Cognition. Fort Worth: Har court Brace Publisher

Muijis, D dan Reynolds, D. (2008). EFFECTIVE TEACHING (Teori dan Aplikasi). Yogyakarta: Pustaka Belajar

Pinahayu, EAR. (2015). Problematika Pembelajaran Matematika pada Pokok Bahasan Eksponen dan Alternatif Pemecahannya. Formatif: Jurnal Ilmiah Pendidikan MIPA, 5(3), 182-191. Retrieved from http://journal.lppunindra.ac.id/index.php/Formatif/article/view/642

Priambodo, CG., Awaludin, AAR.., Alamsyah N. (2017). Pengembangan Perangkat Pembelajaran Berbasis Konstruktivisme dengan Multimedia Interaktif untuk Mengajarkan Konsep Matematika. AKSIOMA: Jurnal Matematika dan Pendidikan Matematika 8(2), 59-67. Retrieved from http://journal.upgris.ac.id/index.php/aksioma/article/view/1819

Purwanto, Ngalim. (2005). Psikologi Pendidikan. Bandung: Remaja Rosdakarya

Suryadi, Ace. 2007. Pemanfaatan ICT dalam Pembelajaran. Jurnal Pendidikan Terbuka dan Jarak Jauh. 8(2): 83-89. Retrieved from https://jurnal.ut.ac.id/index.php/jptjj/article/view/537 
98 | Handayani dan Awaludins: Pengembangan Media Pembelajaran Interaktif ... 